Bwanga

IN response to the request made in these Notes last April we have received the following from Mr. Charles M. White, the District Commissioner at Mwinilunga, Northern Rhodesia :

' Wana (Lunda), wanga (Lwena and Chokwe), and vwanga (Luchazi) is essentially the unseen power behind the concept of witchcraft. I think waya is always the unseen element: the preparation of magical devices is usually the location of the waya, but, as you remark, waya is the magical element of potency and anything naturally harmful in itself, such as a known poison, would not be termed waya. Among the Lunda, Lwena, and Luchazi there is a sharp line between waya in the sense of sorcery and the inherited inherent evil of witchcraft associated with the female sex which manifests itself as rdumba, tushipa, \&c. These latter are never termed waya by the Lunda, Lwena, or Luchazi, but they are termed waya by the Chokwe who seem not to draw this distinction between sorcery (waya) and inherent witchcraft evil of females. I notice that Doke refers to the unseen force of waya as being used for injuring or for healing. I have not encountered the word used in the latter sense among these tribes. Waya here always seems to be a harmful force.'

\title{
Nuffield Scholarships
}

THE trustees of the Nuffield Foundation are awarding scholarships to enable officers of Colonial and Dominion origin, at present in subordinate ranks of the Colonial Service, to qualify for promotion. The scholarships, which will be tenable at any University or similar institution in the British Commonwealth or Colonial Empire, will be awarded by the Trustees on the recommendation of the Colonial Office and the Colonial Government concerned. Applicants must hold the qualifications required for entrance to a University, and should apply through the Heads of their Departments.

\section{Public Manifesto of German Ethnologists assembled at Frankfort-on-Main from I9 to 21 September 1946}

'German ethnologists from the four zones of occupation, assembled at Frankfort, unanimously concur in the opinion that it is the duty of every German to offer his active contribution to the support and promotion of world peace.

'German ethnology, collaborating and peaceably competing with members of the rest of civilized nations, has accumulated abundant information about all races and peoples of the earth. This knowledge ought to become a means of deepening thought and enlarging the outlook at all stages of education and teaching to produce a readiness in the German mind for the understanding and appreciation of other nations.

'All ethnologists in Germany uphold that free and unbiased research which has been banned in this country during the past twelve years. To foster research and to develop its resuscitated spirit, German ethnology must be given a chance and the elementary means to restart its work. It hopes confidently to be supported in its task by the competent authorities in this country and by ethnologists abroad.' 